ROCZNIKI NAUK SPOŁECZNYCH

Tom 11(47), numer 1 - 2019

DOI: http://dx.doi.org/10.18290/rns.2019.47.1-8

AGNIESZKA ZARĘBA

\title{
VII ROTATION OF POLISH MILITARY CONTINGENT IN AFGHANISTAN FROM THE PERSPECTIVE OF POLISH SOLDIERS
}

Poland as a state has participated in peace operations since 1953. These have been arbitration, humanitarian, observation and police operations within the framework of the United Nations (UN), the European Communities (EC), the European Union (EU), the North Atlantic Treaty Organization (NATO), the Organization for Security and Cooperation in Europe (OSCE). In general, most of them have been stabilisation missions which have not carried out military operations. ${ }^{1}$ Only in 2003, NATO's operations changed the nature of the activities of previously peace-keeping missions. They have affected, among others, the soldier training process in the Polish Army (WP).

The Polish Military Contingent in Afghanistan started its operation within the framework of the International Security Assistance Force (ISAF) created on 20.12.2001. Its goal was to promote security in Afghanistan and to protect the United Nations Support Mission in this territory. On 11.08.2003 NATO took the lead of ISAF. $^{2}$ Among the tasks entrusted to ISAF, one can mention, among others: stabilisation operations in cooperation with the Afghan National Security Forces (ANSF), building of combat capability of the Afghan National Army

Dr Agnieszka ZaręBa - Institute of Political Science and Public Administration, John Paul II Catholic University in Lublin; address for correspondence: Al. Racławickie 14, 20-950 Lublin; e-mail: amzareba@vp.pl; ORCID iD: https://orcid.org/0000-0003-1639-0413

${ }^{1}$ In order to become familiar with the activities of Polish stabilization missions, see e.g.: Grzegorz Ciechanowski, Żolnierze polscy w misjach i operacjach pokojowych poza granicami kraju w latach 1953-1989 (Torun: Wydawnictwo Adam Marszałek, 2009), 377; Grzegorz Ciechanowski, Polskie Kontyngenty Wojskowe w operacjach pokojowych 1990-1999 (Toruń: Wydawnictwo Adam Marszałek, 2010), 382; Grzegorz Ciechanowski, Wojsko Polskie w Iraku 2003-2011 (Oświęcim: Napoleon V, 2015), 425.

2 Joanna Modrzejewska-Leśniewska, Afganistan (Warszawa: Wydawnictwo Trio, 2010), 425-453. 
(ANA), support in building combat capabilities of the Afghan National Police (ANP), disarming of illegal armed groups, providing and transferring of humanitarian aid, ensuring security for the reconstruction of the state and supporting the Afghan authorities in combating drug cultivation and trafficking. ${ }^{3}$

The 7th rotation in Afghanistan is described as one of the most difficult military operations, mainly due to the tasks ${ }^{4}$ that were set for the contingent and the political and social conditions at that time. Moreover, as Colonel Piotr Łukasiewicz, the plenipotentiary of the Minister of National Defence for Afghanistan, stated "in 2007 the character of the rebellion in Afghanistan was local and criminal, devoid of planning and coordination. Now it is better planned, and the number, nature and places of incidents testify to the coordination of activities." The 7th rotation encountered difficulties connected not only with the summer Taliban offensive against the Afghan security forces, stabilisation of the situation during parliamentary elections and ensuring security for civilians, additionally there were logistical difficulties caused by volcanic eruptions in Iceland and the destabilisation of the political situation in Kyrgyzstan. ${ }^{6}$ The contingent was commanded by Brigadier General Andrzej Przekwas, who took command in the zone with delay on 27 April 2010, while the stabilisation mission ended on 28 October 2010. The general publicly declared that he expected perseverance, prudence and responsibility, solid and brave execution of tasks from his soldiers. ${ }^{7}$ In order to perform the tasks the commander of the Task Force White Eagle had at his disposal: 1st Armoured Brigade from Wesoła, 3rd Mechanised Brigade

\footnotetext{
${ }^{3}$ Magdalena Trzpil, Afganistan jako największe współczesne wyzwanie dla NATO, 61, accessed December 28, 2017, https://www.bbn.gov.pl/download/1/3178/Raport-MagdalenaTrzpil-Afgani stanjakonajwiększewspolczesnewyzwaniedlaNATO.pdf.

${ }^{4}$ The tasks of the soldiers of the $7^{\text {th }}$ rotation of the Polish Military Contingent in Afghanistan included among others: ensuring the safe conduct of elections in the province, ensuring security in the Afghan Development Zone in Ghazni province, protection of ongoing reconstruction projects in its own responsibility zone, control of the main artery (Kabul-Kandahar route), training of the Afghan army and police. VII zmiana Polski Kontyngent Wojskowy Afganistan, accessed December 28, 2017, http://isaf.wp.mil.pl/plik/file/7_zmiana/informator_7_zmiana.pdf.

5 Podsumowanie VII zmiany PKW Afganistan (komunikat), accessed December 28, 2017, https://finanse.wp.pl/podsumowanie-vii-zmiany-pkw-afganistan-komunikat-6116320163575937a.

${ }^{6}$ On 6-15 April 2010, there were public protests against the authority of President Kurmanbek Bakiyev. Their result was the collapse of his rule and the seizure of power by the interim government headed by Roza Otunbayeva. During the riots and clashes with the police 85 people were killed. The significance of Kyrgyzstan has always resulted from the fact that two zones of influence, Russian and American, have really clashed there. In one country there have been two bases of the aforementioned states. Vicken Cheterian, Rewolucja na nowo, „Le Monde diplomatique” (Polish edition) 2010, no. 5 (51), accessed December 28, 2017, http://monde-diplomatique.p1/LMD51/ index.php?id=1_3.

7 VII zmiana wystartowała, 27.04.2010, accessed December 28, 2017, http://isaf.wp.mil.pl/ pl/1_932.html.
} 
from Lublin, 1st Mazurian Artillery Brigade from Węgorzewo, 2nd Sappers Brigade from Kazun, 5th engineering regiment from Szczecin, 56th regiment of combat helicopters from Inowrocław, 49th regiment of combat helicopters from Pruszcz Gdański, 2nd reconnaissance regiment from Hrubieszów, 15th Mechanised Brigade from Giżycko, 20th Mechanised Brigade from Bartoszyce, 25th Air Assault Brigade from Tomaszów Mazowiecki, 15th anti-aircraft regiment from Gołdap, 1st Pomeranian Logistic Brigade, 2nd communication regiment from Inowrocław, 3rd road and bridge regiment from Chełmno, 10th Logistic Brigade from Opole, Central Group of Psychological Activities from Bydgoszcz, Central Support Group for Civil-Military Cooperation (CIMIC) from Kielce, Military Police. From the official information available on the ministerial website we can learn about numerous projects implemented during the 7th rotation, including: rebuilding of a road in the capital of Ghazni province, expanding the water supply network in the province capital, the construction of a hydroelectric power plant in Gelan and the first kindergarten in Ghazni, the organisation of a seminar on good governance practices, addictions and women's rights, the construction of a conference venue for 500 people, renovation works at the Al-Biruni Mausoleum. ${ }^{8}$ The successes included eliminating 239 rebels, capturing 243 partisans and neutralising several tons of explosives. ${ }^{9} 2,600$ soldiers ${ }^{10}$ took part in the operation, while 6 soldiers died, about 40 were injured. ${ }^{11}$

The aim of this analysis is to present the 7th tour in Afghanistan from the perspective of a soldier. The analysis is in no way a reflection of official accounts of the peace operation. It shows the day-to-day duties of a soldier, the hardships of his service abroad, relations with Afghans, and the requirements that all soldiers have to cope with. This is a case study analysis, which relies not only on the reports from the mission, but on direct conversations with the author of the book "Raport Borsuka. ISAF - nie dla idiotów" ["Badger's Report. ISAF - not for idiots"]. It is worth emphasising that the "Raport Borsuka" ["Badger's Report"] is the first printed account of a soldier of the Polish Army taking part in the mission in Afghanistan. The memories were published under his own name, which in fact required considerable courage from the author. ${ }^{12}$ Robert Polak (born in 1973) is a sergeant of the Polish Army. He served in the 6th Airborne

\footnotetext{
${ }^{8}$ VII zmiana Polski Kontyngent Wojskowy, 3.

9 ARTur Weber, VII zmiana zakończyła misję, 28.10.2010, accessed December 28, 2017, http://isaf.wp.mil.pl/pl/1_1170.html.

${ }^{10} 2,500$ soldiers according to some sources.

${ }^{11}$ Podsumowanie VII zmiany.

${ }^{12}$ It turns out that so far the author has not encountered any trouble on the part of his superiors in connection with the publication of his memoirs. He has even been praised by some officers.
} 
Brigade in Kraków, 3rd Mechanised Brigade in Lublin, 1st Mechanised Division from Legionowo and 2nd Hrubieszów Reconnaissance Regiment. He participated in the Polish Army missions abroad. He was in Syria, twice in Kosovo, twice in Iraq and Afghanistan. He was decorated with the Star of Iraq (twice), the Star of Afghanistan and the Cross for Bravery. After the end of his service he decided to establish the company "BORSUK" ["BADGER"], specialising, among others, in military and shooting trainings. Currently, he is a student of the second degree of national security at the Catholic University of Lublin. The 7th rotation in Afghanistan, that is the events described in the journal, belong, in the opinion of experts, to the most difficult and bloodiest ones. The diary is written in colloquial language, full of emotions, there is some invective. However, it should be remembered that the report was created when the author's life was in danger, he actively participated in the events of that time. ${ }^{13}$ The journal was written almost every day, addressed to colleagues who had earlier asked him for this type of brief account of previous missions. R. Polak had not decided to write a diary before although he himself said in an interview preceding the publication of the journal “ $(\ldots)$ I wrote a couple of pages and then gave it up. I didn't see much sense. No one would believe it. Here I was writing and sending it to my colleagues (...) who were encouraging me". ${ }^{14}$ It is worth asking why R. Polak decided to go to Afghanistan for the mission. It turns out that these were not reasons resulting from the remuneration (as he said about 10,000 for risking life was not too much), while for the author it was a kind of adventure, the willingness to prove himself, as he said: "It is always not enough, a man always wants something more. Adrenalin. For the most part I had the pleasure to serve with such guys" ${ }^{15}$. Similar statements can be heard from most soldiers answering this type of question. They minimise the importance of finances and career development opportunities. ${ }^{16}$ Corporal Jacek Dutkiewicz presented in his journal a slightly different explanation of his participation in the mission. He went on a mission because he wanted to learn, improve his skills, gain additional personal experi-

${ }^{13}$ Marcin Baranowski, "Wstęp," in Robert Polak, Raport Borsuka. ISAF - nie dla idiotów (Oświęcim: Napoleon V, 2015), 7-8.

14 (...) Wystano nas tam na wojnę. I robiliśmy swoje - rozmowa z sierż. Robertem Polakiem (Lublin, 18 II 2015), in Robert Polak, Raport Borsuka. ISAF - nie dla idiotów (Oświęcim: Napoleon V, 2015), 28.

${ }^{15}$ Ibid., 22.

${ }^{16}$ Magdalena Rigamonti And Maksymilian Rigamonti, Straty. Żotnierze z Afganistanu (Warszawa: Dom Wydawniczy PWN, 2015), 11, 33, 61, 118. 
ence. ${ }^{17}$ In this case, the attitude of a professional who wants to broaden his professional skills is revealed.

These considerations were divided into the following problematic issues facilitating the analysis: conditions, service and daily duties, soldier-officer relation, relations with indigenous people. The use of numerous quotes complements the analysis as they reflect the reality and hardships of the peacekeeping operation in Afghanistan. ${ }^{18}$ "Raport Borsuka" ["Badger's Report"] has an additional analytical value, it is a meticulous diary written almost every day during the stabilisation mission. Another similar publication are the memories of Senior Corporal Jacek Dutkiewicz, participant of the 9th rotation in Afghanistan, issued and edited posthumously by Marcin Ogdowski in 2017. ${ }^{19}$ The analysis of "Dziennik Dowódcy Rosomaka" ["Wolverine Commander's Report"] allows us to formulate the conclusion that it is very similar in its content to "Raport Borsuka" ["Badger's Report"]. Both journals are written almost daily, sent by e-mail, describe soldiers' service and duties, are written in colloquial language, but corporal J. Dutkiewicz's description is clearer, contains more details of the operation. ${ }^{20}$ However, most of the accounts available on the publishing market were created post factum and these are not publications written by soldiers. Marcin Ogdowski's blogs (zafganistanu.pl and bezkamuflażu.pl) and publications are accounts of a journalist, ${ }^{21}$ a stabilisation mission observer, similarly, Piotr Langenfeld's reports are also observations of a journalist and photojournalist. Soldier accounts were generally created post factum, e.g. the one by colonel Grzegorz Kaliciak. ${ }^{22}$ Only the authors of the book „Al Kut ostatnia zmiana” ["Al. Kut the last rotation"] (describing the last rotation of the Polish Military Contingent in Iraq) started to write it in the last month of the mission. ${ }^{23}$

\footnotetext{
${ }^{17}$ Jacek Dutkiewicz, Marcin Ogdowski (ed.), Dziennik dowódcy Rosomaka (Kraków: Warbook, 2017), 144.

${ }^{18}$ Invective, dirty words were removed from the quotes.

${ }^{19}$ Ibid., 352.

${ }^{20}$ J. Dutkiewicz, in contrast to R. Polak, gives examples of wrong decisions of the mission commanders (for example, the sought-after rebel was released because "no one knew what to do with him"), examples of erroneous management of military assets. The most controversial was the decision of the mission command regarding the exercises during which four crews of armored vehicles of the rosomak type repulsed the attack of the Afghan tank battalion on the base in Ghazni, while in addition, the same soldiers participating in the attack repulse, in the meantime, covered a breach in the fence. The remaining soldiers and the staff were safe in the shelter and watched the situation. Ibid., 242, 261, 279.

${ }^{21}$ Marcin Ogdowski, Z Afganistanu.pl. Alfabet polskiej misji (Poznań: Ender, 2011), 256.

22 Grzegorz Kaliciak, Karbala. Raport obrony z City Hall (Warszawa: Czarne, 2015), 200; Grzegorz Kaliciak, Afganistan. Odpowiedzieć ogniem (Warszawa: Czarne, 2016), 184.

${ }^{23}$ AL Kut ostatnia zmiana is a collector's item. Only 500 copies appeared and all were distributed among soldiers and their families. „Gazeta Lubuska” published fragments of the book. Piszemy
} 
The first base for Robert Polak during the 7th rotation in Afghanistan was a Fire Base (FB) in GIRO. Fire bases are usually forward, very poorly equipped bases. They hardly resemble large bases (e.g. Bagram) whose main goal is to create conditions similar to those at home (that is, in fact, American). Such a base can be compared to a small town that meets basic needs of soldiers. There are gyms, cinemas, hair salons, shops, for instance, of Adidas and HarleyDavidson. ${ }^{24}$ From a logistics point of view Bagram is the place of the transfer of soldiers, deployed all over Afghanistan. ${ }^{25}$ The description of the fire base starts prosaically. "There are containers with showers. And a lot of water for washing. There are seven washing machines, of which four are automatic and out of order. Only rotor Franias can handle it. There are sand and stones and dust everywhere. There is no cesspool". ${ }^{26}$ Toilets have been replaced with pits in the ground, while the waste and garbage are burned in barrels. "The base is small, with us there are 150 people, about 50 too many. They put us in so-called Brickfield. Eighteen of us sleep in a building without windows, there are windows but filled with sacks. Only concrete and bricks. We look for polystyrene in the dump and stick it to the walls. It will be warmer and brighter (...)". The conditions presented in the journal do not differ from range conditions known to soldiers. We find similar descriptions of fire bases, among others in: a report by journalist and photographer Piotr Langenfeld, who was in Afghanistan in spring 2009 and during the presidential election ${ }^{27}$ and in „Raport dowódcy rosomaka" ["Wolverine Commander's Report"]. ${ }^{28}$ The journal gives an accurate account of the course of the entire mission, individual attacks on the base, impatience with the commanders who do not give consent to an adequate response to offensive attacks. ${ }^{29}$ Despite repeated firing at the fire base in GIRO, the base command did not retaliate. On the one hand, they probably did not want to provoke retaliation from the attackers, while on the other hand, the lack of response from the attacked party increased the opponent's attacks. ${ }^{30}$

\footnotetext{
o tym, co czuliśmy w Iraku. "Al Kut. Ostatnia zmiana” cz. I - bez cenzury, 14. 11.2009, accessed December 28, 2017, http://www.gazetalubuska.pl/artykuly-archiwalne/art/7821425,piszemy-o-tymco-czulismy-w-iraku-al-kut-ostatnia-zmiana-cz-i-bez-cenzury,id,t.html.

${ }^{24}$ Piotr Langenfeld, Afganistan. Dotknątem wojny (Ustroń: Ender, 2011), 20-21.

${ }^{25}$ Anna Wojtacha, Kruchy lód (Warszawa: Carta Blanca, 2012), 209.

${ }^{26}$ Robert Polak, Raport Borsuka. ISAF - nie dla idiotów (Oświęcim: Napoleon V, 2015), 38.

${ }^{27}$ Langenfeld, Afganistan, 154.

${ }^{28}$ Dudkiewicz, Ogdowski (ed.), Raport dowódcy Rosmaka, 29.

${ }^{29}$ Polak, Raport Borsuka, 52.

${ }^{30}$ Marcin Ogdowski, Aktualna sytuacja w PKW, 15.06.2010, accessed December 28, 2017, http://zafganistanu.pl/?m=201006.
} 
Relations with Afghans are presented in different ways in many sources from positive to negative ones. It results, among others, from the ethnically diversified situation in the country ${ }^{31}$ and its difficult history. In "Raport Borsuka" ["Badger's Report"] we find positive personal relationships with Afghans. ${ }^{32}$ Sergeant R. Polak mentions the service with an Asian Security Guard (ASD) member, we learn from it about difficult relations in Afghanistan (the Taliban cut off the Afghan's brother's hand). ${ }^{33}$ Relationships are presented in a slightly different way as far as military cooperation is concerned. It turns out that when Sergeant R. Polak was in the Bagram base, a certain regularity could be observed. About 5 minutes before firing, the Afghans working in the base left their positions. ${ }^{34} \mathrm{We}$ find similar remarks in P. Langenfeld's account of, among others, information transfer by Afghans (so-called informers), who often misled allied forces. ${ }^{35}$ From Sergeant Szymon Mutwicki's reports we learn that operations carried out jointly with the Afghan police often ended in failure because they openly cooperated with the Taliban. ${ }^{36}$ In the account of Corporal J. Dutkiewicz a slightly different problem in the case of cooperation with Afghans appeared. During night rides it happened that the Afghan police attacked allied patrols (as if not knowing the location of the ally, they did not identify them at night, most likely due to the fact that they did not have night-vision goggles). ${ }^{37}$ There were a few reasons for cooperation between the police and the Taliban, among others: fear, convictions or money. ${ }^{38}$ Low morale was a problem in the Afghan armed forces. The only and

${ }^{31}$ Afghanistan as a state has not only complicated history and geopolitical situation, but also social structure. A number of ethnic minorities live in the country, among others Pashtuns about 42\%, Tajiks about $38 \%$, Hazaras about $10 \%$ and Uzbeks about $9 \%$ (estimated data). Pashtuns have dominated in the political sphere for the last 250 years of Afghanistan. A feature of this ethnic group is the division into tribes, groups and families. Present on the entire territory of the country. They have their own unwritten code of honour whose most important values are: equality, bravery, the need to defend honour, hospitality and honesty. Tajiks, the best educated ethnic group in the country, dominate in the largest cities, do not have internal divisions. Hazaras (considered to be the descendants of Genghis Khan) have a very low position because they are Shias. Uzbeks are mostly farmers, live mainly in the north. Krzysztof Korzeniewski, Afganistan. Gdzie reguła jest brak regut (Warszawa: Wydawnictwo Akademickie Dialog, 2006), 119; Grzegorz Indulski and Marek Kęskrawiec, Afganistan. Po co nam ta wojna? (Warszawa: Ringier Axel Springer Polska, 2007), 34; J. Modrzejewska-Leśniewska, Afganistan, 22-26.

32 Interestingly, during an official meeting an Afghan, a representative of power, wanted to offer guests hashish, he could not understand that it was punishable. Polak, Raport Borsuka, 52.

${ }^{33}$ Ibid., 93.

${ }^{34}$ Ibid., 59.

${ }^{35}$ Langeneld, Afganistan, 34.

36 This is the opinion of Sergeant Szymon Mutwicki, participant of the mission in Iraq (2004) and in Afghanistan (2007). Rigamonti and Rigamonti, Straty. Żolnierze z Afganistanu, 120.

${ }^{37}$ Dutkiewicz, Ogdowski (ed.), Raport dowódcy Rosomaka, 105.

${ }^{38}$ Langeneld, Afganistan, 98. 
the most important reason for joining the army was the prospect of relatively large and regularly paid earnings. It has not been possible to create an army ethos over the past few years, the Afghans serving in it still do not have prestige and social respect. The creation of an army ethos is hampered by still existing commitments (loyalty) to the clan (family), then Allah and his earthly intermediaries, and at the very end towards the state. An additional problem of Afghanistan is that its inhabitants do not have a sense of national identity (province residents do not know that they are Afghans). It results from a low level of education (illiteracy). Another problem in the Afghan forces is desertion constantly remaining at the level of $30 \%$, intensifying in the case of the approaching Taliban offensive. ${ }^{39}$

After Sergeant R. Polak moved from the base in Giro to the Fire Operation Base in Ghani (9 May) we can see the escalation of operational activities. An example was the operation in "Four Corners" 40 on 14 May, which was a success. A rebel was captured during IED planting. Several rocket launchers and several $107 \mathrm{~s}$ were seized. The author drew attention to one factor, namely that without the American air support it would be impossible to carry out this task. ${ }^{41}$ The successes of most operational activities were largely conditioned by air support. It is present not only in R. Polak's account but also in that by P. Langenfeld who participated as an observer in setting up of Observation Point „Buckle Eye”. ${ }^{42}$ The activities of the Taliban during the 7th rotation were much more coordinated and organised as evidenced by the attack on Bagram conducted by the Taliban on 20 May. ${ }^{43}$ Subsequent operational activities show not only the difficulties of everyday service but also problems with equipment, the lack of spare parts. ${ }^{44}$ M. Ogdowski mentions a similar problem on his blog. ${ }^{45}$

In the diary we find a description of everyday service as a security commander. On duty for 24 hours (28 May). The commander's duties include announcing an alarm in the event of firing or attack on the base, in addition he is responsible for towers and the entrance gate. Soldiers change at checkpoints on towers every 4 hours, each shift is manned by another cell from the base, for

39 Tomasz Otłowski, Cmentarzysko imperiów. Afganistan 2001-2014 (Warszawa: Rambler, 2012), 58 .

${ }^{40}$ FOUR CORNERS Base.

${ }^{41}$ The quote reflects a certain dependence. "Of course there would be no successes without Americans with their Black Hawks. Our propellers do not fly at night”. Ibid., 60.

${ }^{42}$ Langenfeld, Afganistan, 109-26.

${ }^{43}$ Ibid., 63.

${ }^{44}$ Ibid., 64-65.

45 Marcin Ogdowski, Dawcy po ajdikach, 27.06.2010, accessed December 28, 2017, http://zafganistanu.pl/?m=201006. 
example, airmen, logistics, staff, etc. ${ }^{46}$ Halfway through the mission, soldiers' fatigue and exhaustion are revealed. ${ }^{47} \mathrm{R}$. Polak shows that despite tiredness they performed their duties. ${ }^{48}$ The theme of tiredness appears, among others, in the memories of Private First Class Lukasz Flajszer ${ }^{49}$ and in P. Langenfeld's account. $^{50} \mathrm{~J}$. Dutkiewicz presents the fatigue of soldiers in the context of 10-12 hour rides, which contributed to an increased number of requests for rotation to the country (officially soldiers reported "family problems", unofficially there was also a factor of the lack of the sense of security on the mission). ${ }^{51}$ In "Raport Borsuka" ["Badger's Report"] a big logistics undertaking was the operation in Nani on 9 July, in which significant operational forces took part, it was a success, because all those taking part in the action returned unharmed, although soldiers including sergeant R. Polak were dropped off in the wrong place. ${ }^{52}$

${ }^{46}$ In the journal the author does not hide the distance to officers and staff managing the army. Ibid., 67.

${ }^{47}$ The log contains the following description: "fatigue is creeping in to the platoon. The drivers already have enough. Yesterday we returned at $8 \mathrm{pm}$ from the patrol, and the next patrol at $4 \mathrm{am}$. The guys at the headquarters have no idea that there is only one platoon for patrols. Drivers are on the move for twelve hours. In the evening, we even quarrelled with the platoon commander about it, but he wants to be a captain someday so we toil away". Ibid., 70.

48 The description of the purposefulness of the task raises substantive doubts. "In addition, they set a route through the village. We tore cables, we collapsed eight bridges. Rosomak vehicles are heavy and the bridges just tumbled down. We did not win hearts and minds in this village. And our officer does not acknowledge task failure. But it is possible not enter the village because of the conditions. I rode behind and saw the reaction of these people. I was ashamed. We not only don't help but destroy their work". Several days later: "And again, our lieutenant went to the village, and again we tore some cables, we collapsed the bridges and today we have even collapsed a low wall. Bravo, bravo Bolanda. Surely, we'll be raked tomorrow, I'd also be (...) if some Johns were knocking down my home. Career is more important than common sense". Ibid., 70, 77-78.

${ }^{49}$ Rigamonti and Rigamonti, Straty. Żotnierze z Afganistau, 98.

${ }^{50}$ Langenfeld, Afganistan, 135.

${ }^{51}$ Dutkiewicz, Ogdowski (ed.), Raport dowódcy Rosomaka, 230.

52 "At 3.40 we land, get out in a field near the village. It was wise not to put night-vision goggles on the helmet. Before we got ready, it started to dawn. We go to our place and suddenly we meet Americans. Something is wrong here, they shouldn't be here. After 300 meters, we enter the road, the commander tells me to guard it, he says it's here. It's fine with me, although I have a feeling that we aren't in the right place. We stand by a big compound, I divide the team into two sides and we start to 'act'. After a moment I'm sure we aren't in our place when I see the road and rosomak vehicles on it. According to the plan we were to be at the other side of the village. The operation probably runs smoothly, I even felt the rush of adrenaline when shots rang out close to us. We lay in a pit for a while but after 15 minutes we got bored. Anyway, the operation was over. I got out of it not bad, because we did not have to walk a lot. The operation was successful. A packet of ammunition for AK was found. At 8.00 we were already at the DFAC eating an omelette. We survived, so the operation was a success, although to tell the truth, I was afraid a bit - the more complex the operation, the more victims. It turned out the pilots had made a mistake and dropped us off in the 
We learn from official announcements that Polish soldiers watched over the course of the parliamentary elections in Afghanistan. In the period shortly before and after the elections, there were many terrorist attacks in individual provinces. Residents of individual districts were intimidated to such an extent that only three people voted in one district. ${ }^{53}$ On the day of the election, rocket attacks were made on Kabul and the city of Jalalabad in the east of the country, then there was a rocket attack in Nangarhar province, in the third attack two people were killed. ${ }^{54}$ On this day from "Raport Borsuka" ["Badger's Report"] we learn about firing the base and explosion of an improvised explosive device (IED) behind sergeant R. Polak's rosomak vehicle. Two soldiers were injured. ${ }^{55}$

It seems that there is no soldier who has been on a stabilisation mission that has no symptoms of post-traumatic stress. To a greater or lesser extent operational activities are present in the minds of their participants. It is worth quoting the author of "Raport Borsuka" ["Badger's Report"] when he writes about going on the 9th rotation to Iraq "I was sure I would not come back. I put all my clothes into containers for the poor. I left one pair of jeans, one sweatshirt. I didn't want my wife to have problems with my things afterwards". ${ }^{56}$ The author could not justify his actions rationally, he just had such a feeling. According to R. Polak post-traumatic stress is unavoidable, soldiers are in contact with psychologists from the Veteran's House, but he points out that sometimes bureaucracy prevents the treatment of soldiers. Treatment of soldiers at Szaserów Street differs significantly from the standards used, for example, in the Ramstein base. ${ }^{57}$ In "Raport

wrong place". Ibid., 86-87. The pilots' mistake did not prevent the implementation of the whole task, it would have been worse if it had led to losses in people and equipment.

${ }^{53}$ Emma Graham-Harrison, Paul Tait and Ron Popeski, Afghanistan Announces Last Set of Election Results, accessed December 27, 2017, https://af.reuters.com/article/worldNews/idAFTRE 6B01YQ20101201?sp=true.

54 Ataki rakietowe przed otwarciem lokali wyborczych, accessed December 27, 2017, https://euroislam.pl/ataki-rakietowe-przed-otwarciem-lokali-wyborczych/.

${ }^{55}$ In the journal we find a description of operational activities on the day of the parliamentary election, when one rocket fell into the tent of the 2 nd Company. Three people got burnt. Sergeant R. Polak was sent "as a reserve of ORF and it happened what I was always afraid of. Fortunately, the Afghan gawked and fired this device too late. The IED exploded behind the car. When dust rose, those few seconds when I asked if everyone was ok ... it was an eternity for me. Piotrek and Mariusz were outside the vehicle. Relief that they are alive and then fear when Piotrek says he got it. Fortunately, we had a medic on board. I helped him cut the uniform and dress the hand. Only after returning to the base, it turned out that Maniek also got hit. (...). The spokesperson of the PMC Afghanistan in an interview with the press said that the election was relatively calm, nothing serious was noted. A total of 7 victims one day, and all in all nothing serious". The discrepancy between the press releases and the reality of the stabilisation mission is significant. Ibid., 108.

56 (...) Wystano nas tam, 23.

${ }^{57}$ Ibid., 23-24. 
Borsuka” ["Badger's Report”] and „Raport Dowódcy Rosomaka” [“Wolverine Commander's Report"] there is no description of the relationship between soldiers, this kind of community that is born in operational activities. Probably because the recipients of both reports were soldiers and their families. We find the descriptions of ties and their characteristics in the cited publication by Rigamontis. ${ }^{58}$

It seems that the soldier-officer relationship should be treated as a separate issue. In "Raport Borsuka" ["Badger's Report"] this topic appears in several places. It must be openly stated that the journal contains numerous negative remarks about superiors. We can presume that it resulted from difficult conditions of mission organisation and the failures of military equipment. However, despite the criticism, the author openly states that "it is known that an officer sometimes has to bark at subordinates, but above all he should take care of them. In a sense, authority is service to soldiers. Certainly, a bad officer is someone who does not listen to advice, and wants to do any task at all costs according to his method do not talk back and forward!. In Afghanistan, I was fortunate to have an officer who could talk to us, sometimes to explain what was going on, why we did this that way. I know that he also often fought for us. However, when he failed we focused our dissatisfaction on him". ${ }^{59}$ The author admits that there is a barrier

${ }^{58}$ Rigamonti and Rigamonti, Straty. Żotnierze z Afganistau, 30, 59.

$59 \mathrm{Ibid}$., 25. On 21 June, a visit of the president, foreign affairs and defence ministers took place. "Today there's a visit of VIPs from Poland. They appoint 5 from each platoon. Here Marcin appoints those who have beards, this is part of a joke, because of course everyone has to shave. Surely we don't give a damn about the order. They won't roll us because there will be no one to do the job. There are Komorowski, (...) Klich, Sikorski (...), general Koziej. (...) They answer a few questions, they live in a different matrix than we. (...) Komiks and I take a strategic place near the soup (...) At the end I have a photo taken with Sikorski. (...) Earlier, I met him in Iraq, when he visited our contingent as the Minister of Defence - and they lied to him there too". Next on 23 July there was a meeting with Brigadier General A. Przekwas. "Today we had a long-awaited meeting with the general. He should have such a meeting once a month but he had avoided them for so long that he finally had to. (...) His subordinates lie to him or he doesn't want to see the truth. He answered every question we asked saying that we only see a piece of the whole, and he has already been in the army for 28 years and he has been on four missions, so he knows better. Disgust has remained after talking to (...). I asked him a question about the shelter near our huts, which had been tumbled for months. He invited me to report about this shelter in two months' time". Polak, Raport Borsuka, 81 and 91. J. Dutkiewicz presents a more radical look at the problem of the Polish Army. “(...) It is necessary to depart from the old communist way of thinking, in which there were grunts and great staff. In which a stupid or even a dumb soldier was the best, because it was easy to manipulate him. (...) The basis for the transformation of the Polish Army must be not only the exchange of devices, equipment of soldiers (...). It is important but first of all the mentality of commanders must change. And as their mentality can't be changed, there is only one solution: to change commanders". J. Dutkiewicz wrote these bitter words in 2012 in one of the mails to his sister. His trainings for soldiers were not limited to a standard training only. He organised summer 
between officers and soldiers, as evidenced by the statement: "Unfortunately, I have never encountered a situation in which an officer being promoted would thank his soldiers." ${ }^{\circ 0}$ After all, the army operates, officers and generals are promoted thanks to perseverance, endurance, accomplishment of tasks assigned to particular soldiers and their organisational units. As it was mentioned earlier, Corporal J. Dutkiewicz many times openly criticises his superiors, their way of thinking, of making decisions. ${ }^{61}$

"Raport Borsuka" ["Badger's Report"] does not present the 7th rotation from the perspective of successes or failures that the contingent had. It does not mention individual tasks, engineering projects present in numerous documents available to the public. It shows real life of the contingent, daily duties, service, and everyday hardships. In fact, we learn about the functioning of a peacekeeping operation by means of an induction method, from the detail to the general. It should be noted that this is a subjective picture created as a result of Sergeant Robert Polak's experiences. The educational aspect of journals of this type is extremely important. This analysis does not contain the description of the used military equipment, because it was not the goal of the analysis. The most important was the description of the 7th rotation in Afghanistan from the perspective of a soldier, his experiences and emotions from that period. The analysis of the report shows how much such accounts and testimonies that depict the realities of peacekeeping missions are needed. The film entitled "Karbala," ${ }^{62}$ presenting the actions of Polish soldiers in Iraq, appeared recently in the Polish film library. It is based on the memories of Lieutenant Colonel Grzegorz Kaliciak, a defender of the City Hall. At the end of the film significant words are said: "We were not prepared for it," and such statements can be found also, e.g. in interviews with soldiers who served there. ${ }^{63}$

To summarise this analysis, it is worth using a quotation from the last pages of the journal: "was it worth it? I and others who managed to come back without

and winter marches, he ran with them in forests, waded in rivers. Dutkiewicz, Ogdowski (ed.), Raport dowódcy Rosomaka, 332.

${ }^{60}$ The problem of the relationship between a private and an officer is much more complex. It results from the way of commanding the army, the problem of leadership in the army. In the American army these problems are solved in a different way than in the Polish, Lithuanian, Russian or Ukrainian armies.

${ }^{61}$ Ibid., 41, 92, 101, 102, 113, 115, 120, 122, 187, 230, 242.

${ }^{62}$ Karbala, director K. Łukasiewicz, 2015, 115 min.

63 "In Poland we were trained at a shooting range. We shot at paper targets. There, every day, we had to shoot at people - even if they were terrorists ready to kill us, we always had a face in front of us" - Lt. Col. Grzegorz Kaliciak said in an interview given to Karolina Przewrocka. Karolina Przewrocka, Kali z Karbali. Opowieść dowódcy oddziału, który obronit City Hall, accessed December 27, 2017, weekend.gazeta.pl. 
major physical injuries can say that it was worth it. I saw the country, the people and who a 'terrorist' really is in this world; I proved myself in a certain way. And those who did not get lucky? They sacrificed their lives and health for other people's interests. But it's so Polish." ${ }^{64}$ A sceptical position of a soldier assessing the Polish Military Contingent. Some analysts will say that as a participant of the events, he should not judge senior Polish Army officers, their actions, question orders. It turns out that this is not a single voice in the polemic. There are more such voices on internet forums, blogs, reports from individual missions.

\section{BIBLIOGRAPHY}

Ataki rakietowe przed otwarciem lokali wyborczych. Accessed December 27, 2017. https://euroislam.pl/ataki-rakietowe-przed-otwarciem-lokali-wyborczych/.

Baranowski, Marcin. "Wstęp." In Robert Polak, Raport Borsuka. ISAF - nie dla idiotów, 7-8. Oświęcim: Napoleon V, 2015.

Cheterian, Vicken. "Rewolucja na nowo." Le Monde diplomatique (Polish edition) 2010, no. 5(51). http://monde-diplomatique.pl/LMD51/index.php?id=1_3.

Ciechanowski, Grzegorz. Polskie Kontyngenty Wojskowe w operacjach pokojowych 1990-1999. Toruń: Wydawnictwo Adam Marszałek, 2010.

Ciechanowski, Grzegorz. Wojsko Polskie w Iraku 2003-2011. Oświęcim: Napoleon V, 2015.

Ciechanowski, Grzegorz. Żołnierze polscy w misjach i operacjach pokojowych poza granicami kraju w latach 1953-1989. Torun: Wydawnictwo Adam Marszałek, 2009.

Dutkiewicz, Jacek, Marcin Ogdowski ed., Raport dowódcy Rosomaka. Kraków: Warbook, 2017.

Graham-Harrison, Emma, Paul Tait, Ron Popeski. Afghanistan announces last set of election results. Accessed December 27, 2017. https://af.reuters.com/article/worldNews/idAFTRE6B 01YQ20101201?sp=true.

Indulski, Grzegorz, Marek Kęskrawiec. Afganistan. Po co nam ta wojna? Warszawa: Ringier Axel Springer Polska, 2007.

Kaliciak, Grzegorz. Afganistan. Odpowiedzieć ogniem. Warszawa, 2016.

Kaliciak, Grzegorz. Karbala. Raport obrony z City Hall. Warszawa, 2015.

Karbala, director Krzysztof Łukaszewicz, 2015, 115 min.

Korzeniewski, Krzysztof. Afganistan. Gdzie regułą jest brak reguł. Warszawa: Wydawnictwo Akademickie Dialog, 2006.

Langenfeld, Piotr. Afganistan. Dotknąłem wojny. Ustroń: Ender, 2011.

Modrzejewska-Leśniewska Joanna. Afganistan. Warszawa: Wydawnictwo Trio, 2010.

Ogdowski, Marcin. Aktualna sytuacja w PKW, 15.06.2010. Accessed December 28, 2017. http:// zafganistanu.pl/?m=201006.

Ogdowski, Marcin. Dawcy po ajdikach, 27.06.2010. Accessed December 28, 2017. http://zafganistanu.pl/?m=201006.

Ogdowski, Marcin. Z Afganistanu.pl. Alfabet polskiej misji. Poznań: Ender, 2011.

Otłowski, Tomasz, Cmentarzysko imperiów. Afganistan 2001-2014. Warszawa: Rambler, 2012.

\footnotetext{
${ }^{64}$ PolaK, Raport Borsuka, 114.
} 
Piszemy o tym, co czuliśmy w Iraku. “Al Kut. Ostatnia zmiana” cz. I - bez cenzury, 14.11.2009. Accessed December 28, 2017. http://www.gazetalubuska.pl/artykuly-archiwalne/art/782 1425, piszemy-o-tym-co-czulismy-w-iraku-al-kut-ostatnia-zmiana-cz-i-bez-cenzury,id,t.html.

Podsumowanie VII zmiany PKW Afganistan (komunikat). Accessed December 28, 2017. https://finanse.wp.pl/podsumowanie-vii-zmiany-pkw-afganistan-komunikat-6116320163575 937a.

Polak, Robert. Raport Borsuka. ISAF - nie dla idiotów. Oświęcim: Napoleon V, 2015.

Przewrocka Karolina, Kali z Karbali. Opowieść dowódcy oddziału, który obronił City Hall. Accessed December 27, 2017. weekend.gazeta.pl.

Rigamonti, Magdalena, Maksymilian Rigamonti. Straty. Żołnierze z Afganistanu. Warszawa, 2015.

Trzpil, Magdalena. Afganistan jako największe współczesne wyzwanie dla NATO. Accessed December 28, 2017. shttps://www.bbn.gov.pl/download/1/3178/Raport-MagdalenaTrzpilAfganistanjakonajwiekszewspolczesnewyzwaniedlaNATO.pdf.

VII zmiana Polski Kontyngent Wojskowy Afganistan. Accessed December 28, 2017. http://isaf. wp.mil.pl/plik/file/7_zmiana/informator_7_zmiana.pdf.

VII zmiana wystartowała, 27.04.2010. Accessed December 28, 2017. http://isaf.wp.mil.pl/pl/1_ 932.html.

Weber, Artur. VII zmiana zakończyła misję. 28.10.2010. Accessed December 28, 2017. http://isaf.wp.mil.pl/pl/1_1170.html.

Wojtacha, Anna. Kruchy lód. Warszawa: Carta Blanca, 2012.

(...) Wysłano nas tam na wojnę. I robiliśmy swoje - rozmowa z sierż. Robert Polak (Lublin, 18 II 2015). In Robert Polak, Raport Borsuka. ISAF - nie dla idiotów. Oświęcim: Napoleon V, 2015, p. 28.

\section{ROTATION OF POLISH MILITARY CONTINGENT IN AFGHANISTAN FROM THE PERSPECTIVE OF POLISH SOLDIERS}

\section{S u m m ary}

The 7th rotation in Afghanistan is described as one of the most difficult military operations, mainly due to the tasks that were set for the contingent and the political and social conditions at that time. The main aim of analysis is to present VII rotation in Afghanistan from soldier's perspective. The analyze is not any reflection of an official relation from peace operation. There are a lot of everyday soldier's duties and requirements what soldiers have to deal with. An article consists of description operations, conditions, services and soldier-officer relationship. The use of numerous quotes will reflect the realities and hardships of a peacekeeping operation in Afghanistan. It is case study analysis supplemented with sources of a similar nature.

Key words: International Security Assistance Force-ISAF; Task Force White Eagle - TF WE; Afghanistan. 


\section{ZMIANA POLSKIEGO KONTYNGENTU WOJSKOWEGO W AFGANISTANIE Z PERSPEKTYWY POLSKICH ŻOŁNIERZY}

\section{Streszczenie}

VII zmiana w Afganistanie jest określana jako jedna z najtrudniejszych operacji stabilizacyjnych, przede wszystkim ze względu na zadania jakie były stawiane kontyngentowi (przede wszystkim ze względu na zapewnienie bezpieczeństwa w trakcie wyborów parlamentarnych), oraz warunki polityczno-społeczne w tamtym czasie. Celem niniejszej analizy jest zaprezentowanie VII zmiany w Afganistanie z perspektywy żołnierza. Analiza nie jest w żaden sposób odzwierciedleniem oficjalnych relacji z operacji pokojowej. Pokazuje codzienne obowiązki żołnierza, trud służby za granicą, relacje z Afgańczykami oraz wymagania, z jakimi muszą sobie radzić szeregowi żołnierze. Jest to analiza case study, uzupełniona źródłami o podobnym charakterze.

Slowa kluczowe: Polski Kontyngent Wojskowy - ISAF; Task Force White Eagle - TF WE; Afganistan. 